\title{
Comedia del Recebimiento de Bartolomé Cairasco de Figueroa: texto y espectáculo
}

\author{
JOSÉ ISMAEL GuTIÉRREZ*
}

Resumen:

La Comedia del Recebimiento que se hizo al Reverendísimo Señor don Fernando de Rueda, obispo de Canarias, el día 8 de mayo de 1582, es una pieza teatral breve del escritor canario Bartolomé Cairasco de Figueroa. Perteneciente al llamado teatro "de entradas", el cual incorpora a la representación dramatúrgica elementos festivos de carácter parateatral, la comedia cairasquiana enlaza con la retórica renacentista española de la época; pero, dada su vinculación espacial a la isla de Gran Canaria, aclimata temas y facetas de la realidad inmediata reconocibles para el público isleño.

Palabras clave:

Literatura canaria, teatro alegórico, comedia, Renacimiento, siglos XVI y XVII, colonialismo

Con anterioridad al Siglo de las Luces, periodo en que la integración de la cultura canaria en el concierto nacional y europeo indujo a algunas de sus más célebres figuras (Tomás de Iriarte, José de Clavijo y Fajardo, Antonio Saviñón y Yáñez, José de Viera y Clavijo) a dedicarse a diversas actividades teatrales, descuellan en

* Doctor en Filología y profesor de Teoría de la Literatura en la Universidad de Las Palmas de Gran Canaria 
el lento proceso histórico del teatro del archipiélago atlántico, en concreto el que va del siglo XVI al XVII, dos únicas personalidades, separadas una de la otra (si nos atenemos a las fechas de gestación de sendas producciones dramatúrgicas) por más de siete décadas: el grancanario Bartolomé Cairasco de Figueroa (1538-1610) y el palmero Juan Bautista Poggio Monteverde (1631-1707), binomio al que puede incorporarse, con ciertas reticencias, un tercer autor que pronto trascendería el marco geográfico que lo vio nacer: el tinerfeño José de Anchieta (1534-1597), quien desde muy joven marchó a Coimbra y posteriormente a Brasil, donde, imbricando la tradición española quinientista con elementos culturales indígenas, elaboró un original corpus dramático de carácter religioso que supo convertir en eficaz herramienta evangelizadora, de la que el misionero jesuita sacó el máximo partido. Fuera de esta escasez de nombres, el panorama de la dramaturgia canaria de este vasto intervalo de tiempo cuenta tan sólo con una exigua lista de autores cuyas obras lamentablemente se han perdido. ${ }^{1}$ La documentación de la época y algunos catálogos bibliográficos incluyen vagas menciones a comedias, piezas sacramentales, loas y entremeses que desgraciadamente no han llegado hasta nosotros. La excepción a la regla son dos textos anónimos, pertenecientes a la tradición mariana: la Comedia famosa de los guanches de Tenerife y aparecimiento y milagros de Nuestra Señora de la Candelaria, de principios del xvII, y el Diálogo histórico, en que se descrive la maravillosa tradición y aparecimiento de la santíssima imagen de N. Señora de la Peña, en la más afortunada isla de Fuerteventura, una de las Canarias, obra impresa en Madrid en 1700, pero representada en Betancuria (Fuerteventura) en 1675 durante la octava de la Virgen. ${ }^{2}$

Sin embargo, la deficitaria producción dramática legada por el Siglo de Oro en las Islas constituye un espejismo que no avala, con argumentos suficientes, la presencia de un desierto absoluto en la praxis escénica insular. Antes bien, como ha señalado el padre Sebastián Padrón Acosta, teniendo en cuenta que los objetivos de la

1 Algunos de los nombres a los que se suele hacer referencia son Juan de Tobar, Pedro de Medina, Juan de Centellas, Matías de Mato, Francisco González, Diego Bravo de Acuña, Francisco Rodríguez Sardo, Juan Ceverio de Vera, Francisco Valcárcel y Lugo, Diego Ramos del Castillo, Antonio de Viana (1578-?) o Diego Durón.

2 Cfr. Martín Montenegro (477-495). 
conquista eran la propagación de la doctrina cristiana y la anexión del Archipiélago a la corona de Castilla, es justo suponer que las representaciones dramáticas en el interior de los templos isleños principiasen ya a finales del siglo XV (Padrón Acosta 26). Y Luis Alemany, más recientemente, ha confirmado que la lentitud con que se implantó en Canarias el teatro, que en sus comienzos siguió la estela de los modelos dramáticos peninsulares, no obstaculizó que antes de que transcurriera un siglo de la castellanización del territorio insular - las Islas fueron conquistadas entre 1402 y $1496-$, se contase ya con una actividad dramática regular, que incluía representaciones de autos sacramentales de Calderón de la Barca (1600-1681) y de otros autores foráneos durante las solemnidades religiosas, como el Corpus Christi, además de obras compuestas y estrenadas por escritores nativos (Alemany 7-8).

Con su magna obra de épica sagrada, titulada Templo militante, trivmphos de virtudes, festividades y vidas de Santos, que se publicó entre 1602 y 1614, la no menos impresionante Esdruxúlea de varios elogios y canciones en alabança de diversos sugetos, aún inédita, o una serie de composiciones dispersas escritas en verso, Cairasco de Figueroa es considerado hasta la fecha como el primer poeta de nombre conocido en las Islas Canarias. Además, por la realización de un corpus de obras teatrales cuantitativamente modesto, pero sustancioso en componentes culturales e históricos, así como poseedor de unos valores literarios que no desmerecen frente a los de otras piezas forjadas por algunos autores españoles contemporáneos de mayor renombre, se le adjudica también el merecido título de fundador de la dramaturgia en las Islas.

Dejando a un lado las piezas que se hallan en paradero desconocido, como el entremés representado en la ciudad de Las Palmas de Gran Canaria, en la catedral, el 15 de agosto de 1558, la comedia puesta en escena para recibir al obispo don Fernández Suárez de Figueroa (1588) y la escenificada con motivo de la llegada del obispo don Francisco Martínez de Cenicero, en 1597, así como la aún no exhumada Comedia representada al obispo de Canarias don Cristóbal Vela, año de 1576, con motivo de su incorporación a la diócesis, ${ }^{3}$ cuatro son las obras cairasquianas a las que, de momento, es posible

3 El manuscrito de la obra se encuentra en un volumen de la Colección Salazar, que se conserva en la Real Academia de la Historia en Madrid, códice L-10 (Millares Carlo y Hernández Suárez 126). 
acceder a través de la edición de 1957 preparada por el investigador rumano afincado en Tenerife Alejandro Cioranescu; títulos sintomáticos todos de la fuerte y prolongada dependencia que la actividad teatral de nuestro canónigo mantuvo con las obligaciones eclesiásticas que, a lo largo de más de cuarenta años, le impusieron los distintos cargos que desempeñó en el Cabildo catedralicio al que pertenecía. ${ }^{4}$ La Comedia del Alma y la Tragedia de Santa Susana, ${ }^{5}$ compuestas para la fiesta del Corpus de no se sabe cuándo, la Tragedia y martirio de Santa Caterina de Alejandría y la Comedia del Recebimiento que se hizo al Reverendísimo Señor don Fernando de Rueda, obispo de Canarias, el día 8 de mayo de 1582, de la que me ocuparé en las siguientes líneas, nutren la escasa nómina de textos teatrales cairasquianos que han llegado intactos hasta el presente.

La última de las composiciones teatrales viene a complementar la vertiente hagiográfica, de asunto bíblico y litúrgico del teatro del autor, agregando a la misma una pincelada de retórica ditirámbica que se hace eco de la finalidad celebrativa y del talante encomiástico con que fue concebida, sin olvidarnos de que la intención conmemorativa de la Comedia del Recebimiento, que es como se conoce abreviadamente esta composición teatral, debió traducirse, seguramente, en una espectacular puesta en escena, ya que, si la Tragedia y martirio de Santa Caterina, la de Santa Susana y la Comedia del Alma se encaminan, en líneas generales, a la exaltación de existencias virtuosas y santificadas o a la exposición de lides espirituales, la anterior modalidad, más expresamente que esta otra, muestra una incuestionable fidelidad hacia la teocracia pontifical en la que se inscribe, enmarcándose por tanto en una dimensión de espectáculo parateatral que en el siglo XVI ofrecía distintas posibilidades de desarrollo: las fiestas y ceremonias en sus múltiples y amplias expresiones (bautizos, bodas, defunciones, banquetes, conmemoraciones religiosas, romerías, coronaciones de reyes, recibimientos, santificaciones, diversiones de carnaval, canciones y manifestacio-

4 A los trece años tomó posesión de una canonjía que se le había concedido. En 1559 tuvo que ordenarse sacerdote en el municipio de Agaete; desde 1572 figura como secretario del Cabildo de la Catedral de Las Palmas; en 1593 es nombrado contador de dicho Cabildo y en 1605 fue recibido como prior con retención de la canonjía que disfrutaba hasta entonces.

5 Sobre la Tragedia de Santa Susana consúltese el estudio de Galván González. 
nes folklóricas, vida pública, etcétera), en una rica complejidad que englobaba desde la fiesta-espectáculo a la fiesta-participación. ${ }^{6}$

Hemos de reconocer, antes de adentrarnos en el comentario de esta obra, un hecho innegable: frente a la vena sacra, el teatro profano de Cairasco, canalizado en las piezas escritas en homenaje a los obispos Vela, Rueda, Figueroa y Cenicero (al menos la segunda, que es la única de este cariz dada a conocer hasta el momento) posee menor entidad dramática que las anteriores. De carácter alegórico, como corresponde al fin laudatorio que persigue, la Comedia del Recebimiento ostenta unos valores de orden genérico inferiores a los de las otras composiciones dramatúrgicas del autor, aunque no oculte las particularidades del espíritu contrarreformista instituido desde la segunda mitad de la centuria, así como los signos específicos de las preferencias métricas cairasquianas ${ }^{7} \mathrm{y}$ de un imaginario temático-ficcional coherente con las preocupaciones habituales en su poética. Compuesta con motivo de la solemne entrada en Las Palmas del nuevo obispo don Fernando de Rueda, cuyo pontificado se extendió desde 1580 hasta su muerte, acaecida cinco años después, ${ }^{8}$ la obrita en cuestión se divide en tres breves escenas de variable formato (equivalentes en conjunto a una

${ }^{6}$ La fiesta, asociada inmemorialmente a los conceptos de lo sagrado, de lo ritual, de lo ceremonial, supuso en el siglo XVI un medio de comunicación entre los miembros de la sociedad, una participación colectiva en sus ritos y creencias, con el objetivo de reforzar el poder de las instituciones y de las autoridades. En América Latina también tuvieron lugar por la misma época celebraciones semejantes a imitación de las fiestas renacentistas del continente europeo. La ciudad se decoraba con arcos de triunfo a la romana que "cerraban las puertas verdaderas o fingidas. En la plaza, centro de la actividad lugareña, la pirotecnia de los fuegos artificiales y los artificios de agua redoblaban su importancia real. El uso de elegantes tapicerías alegraban el frontis de las casas" (Pereira Salas 19). Un montaje que se desplegaba sobre todo en zonas urbanas y que pasará de España a las tierras conquistadas por la corona española.

7 En especial, los versos esdrújulos y las rimas proparoxítonas, que se convirtieron en marcas inconfundibles del estilo de Cairasco de Figueroa.

8 Fernando de Rueda fue nombrado obispo de Canaria el 22 de junio de 1580 por traslado de don Cristóbal Vela a Burgos. Nació en Puentedei, en las montañas de Burgos. Era teólogo y canónigo lectoral de Ávila. Había sido discípulo en Salamanca de Bartolomé de Torres y opositó a su canonjía con don Cristóbal Vela. A finales de diciembre de 1580 tomó posesión de su obispado por medio de su apoderado y provisor, el licenciado don Andrés de Soto. 
jornada del teatro aurisecular) y sin mucha conexión interna entre una y otra. ${ }^{9} \mathrm{Y}$ no sólo es una de las pocas que lleva indicación de fecha (1582), sino que hay datos que certifican que en los preparativos del festejo los organizadores invirtieron todo un año. La acción, como el mismo acontecimiento central en torno al que gira, se orienta hacia la inmediatez y el espacio insular. En la dramatización, efectivamente, se otorga un notable protagonismo a la presencia del pueblo canario que hace la ofrenda, recreado a partir de su identidad: éste aparece metonimizado en las figuras de Guía y de Gáldar (dos municipios del norte de Gran Canaria) y del héroe guanche Doramas, al tiempo que el paisaje autóctono se metaforiza y mitifica a partir de modelos tomados del acervo literario de la Antigüedad, perfilándose así como un hito inaugural en la forja de lo que Eugenio Padorno ha denominado la "tradición interna" en la literatura canaria, ${ }^{10}$ originada desde el preciso instante en que los moldes estéticos injertados en las Islas después de la conquista

El 6 de mayo de 1582 fue recibido por su cabildo. El 14 de agosto de 1582 empezó la visita pastoral de la Catedral de Santa Ana, en Las Palmas. Entre sus veintisiete mandatos citemos el que ordena sacar del sagrario los huesos de los santos y los referentes a la doctrina a la que tenían que asistir también los esclavos. Continuó el expediente de la fundación de las Bernardas; deshizo la unión de la iglesia del municipio de Teror con la Catedral, existente desde tiempos del obispo Fernando Vázquez de Arce (1513-1522). En el Cabildo 14 de septiembre de 1582 expone la necesidad de un seminario y propone la casa del arcediano de Tenerife. El 7 de octubre de ese mismo año aparece visitando el municipio de Agaete y en julio de 1583 visita la isla de La Palma, año en que se construyó la hermosa puerta principal de la iglesia parroquial de El Salvador, en Santa Cruz, capital de la isla. En 1585 donó a los agustinos la ermita de San Sebastián de Icod para que fundasen un convento, y el 16 de junio fallecería en la ciudad de La Laguna (Tenerife); fue sepultado en la iglesia de la Concepción de aquella ciudad. Diversos testimonios aseguran que algunos años después hallaron su cuerpo con sus vestiduras incorruptas.

${ }^{9}$ Alejandro Cioranescu la califica de "breve y agradable improvisación", de "ingenioso artificio" en el que la "declamación festiva" minimiza la acción teatral y el argumento, que es bien simple. Tampoco halla el estudioso rumano interés en los caracteres de los personajes, pero sí un valor histórico indudable por ser el texto más antiguo que se refiere al caudillo aborigen Doramas (Cioranescu, "El teatro" 83-85).

10 Dos factores en la obra de Cairasco que, según Padorno, han contribuido a la formación de esta tradición interna son la enunciación de la naturaleza 
y a lo largo del escalonado proceso colonizador se modifican sensiblemente en tanto que la mirada que los literatos proyectan sobre la naturaleza circundante, sobre esa realidad otra, distinta a la europea, acusa un tímido gesto de incipiente criollismo. ${ }^{11}$ Este criollismo germinal, intensificado por la toma de conciencia de sentirse en una localización ultraperiférica respecto a la cultura metropolitana, se manifiesta en este caso no solamente en la atención prestada al paisaje rural y urbano familiar para el canónigo y su auditorio, sino también en la contemporaneidad del asunto que aborda la obra y en la formulación de una propuesta, insólita hasta entonces en el teatro de Canarias, consistente en integrar a la tradición cultural y literaria española la presencia de motivos aborígenes. Por consiguiente, si por su estructura, desarrollo y concepción dramática, la Comedia del Recebimiento, representada dos días después de la auténtica recepción del nuevo prelado, ${ }^{12}$ no nos depara muchas sorpresas, no puede escapársenos el hallazgo, que incide en la singularidad del texto, de la mitificación, realizada en la esfera teatral discursiva, de lo autóctono insular por medio de una idealización de elementos espaciales verídicos, de figuras históricas prehispánicas que, al doblegarse bajo el peso de una vocación mítica fundacional, se reinsertan ampliamente en una galaxia de tópicos exógenos, entre los que destaca el locus amoenus. El pasado indígena, resucitado, entra en el contexto de lo legendario; se colo-

canaria y su compleja adscripción estética (Padorno, "Un 'Canario cántico'” 33-37). Véase también Padorno (“Unas notas” 42-45). Asimismo, Carlos Brito Díaz atribuye a Cairasco el haber iniciado una tradición (o microtradición, en palabras de Sánchez Robayna) en las letras de las Islas basada en "la mirada hacia la tierra" (Brito Díaz, “El teatro” 115).

11 En la medida en que las distintas secuencias derivan hacia el estatismo o muestran cierta impotencia por superar la situación planteada al comienzo, se puede hablar de una acción débil sin ninguna complejidad. El texto más bien se organiza en una serie de "situaciones", estructuras o constelaciones de fuerzas, sobre todo en lo que atañe a la relación entre los personajes, en un momento dado, y, especialmente, está dominado por lo que podemos llamar el "suceso", entendiendo por tal la actuación de los personajes que no alteran la situación en la que se produce.

12 Aunque Rueda había tomado posesión de su cargo a fines de diciembre de 1580, no fue recibido por el Cabildo Catedral hasta el 6 de mayo del 82. Cfr. Cazorla León y Sánchez Rodríguez (151). 
ca en el mismo plano de significación que las alusiones a la mitología grecolatina, con la que se enhebran. Como obedeciendo a un afán universalista que insistiera en el engarce de ingredientes de la historia y de la topografía isleñas en el concierto cultural europeo para dignificarlos y hacerlos merecedores del mismo reconocimiento y prestigio, Cairasco instala las notas que él estima representativas de la canariedad en la base de una tradición mitológica extraña de la que se apropia con total derecho.

Díez Borque ve tanto en esta obra de nuestro escritor como en otra del mismo siglo, La sacramental histriada (sic) donde se toca la entrada y recebimiento que se hizo a la serenísima infanta doña Catherina de Austria en Saboya, sobre la boda de la hija de Felipe II con el Duque de Saboya (1585), testimonios de "unas costumbres celebrativas de acontecimientos con piezas teatrales, que quizá se integrarían, coherentemente, en la estructura de la fiesta" (Díez Borque, Los géneros 101). La representación de esta pieza dramática resultó ser, en efecto, un acto más de los diversos que se sucedieron con motivo de la recepción del nuevo prelado, a modo de variante cívico-religiosa del teatro de entradas, que es como se conocen los recibimientos apoteósicos y teatrales que proliferaron en la Italia de los últimos años del Medievo y del primer Renacimiento, organizados por las ciudades en honor a un príncipe (que garantizaba la unidad y la seguridad del pueblo) a quien, mediante un espectáculo de estirpe protocolaria, mostraban su vinculación e incondicional vasallaje, ${ }^{13}$ sólo que la Comedia del Recebimiento, por ser alegorización del poder eclesiástico, no del político, está desprovista naturalmente del mismo carácter mundano que la fiesta de recepción a príncipes y monarcas. ${ }^{14}$

En la escena I, la Sabiduría le comunica a la Curiosidad la llegada del Reverendísimo Obispo don Fernando de Rueda a la diócesis

13 Este tipo de representaciones lo ha examinado Bobes Naves (304-307).

14 La práctica del teatro de "entradas" se extendió también hasta Hispanoamérica, donde se documenta hasta bien entrado el siglo XVIII. Su finalidad era el afianzamiento de la colonización en el aspecto ideológico. Con tal propósito los espacios de la ciudad de teatralizaban para reiterar el vasallaje de la población. En su estudio sobre el teatro venezolano, de orígenes más tardíos que el peruano o el mexicano, Leonardo Azparren Giménez distingue en esta modalidad los siguientes componentes: “1. La plaza: espacio del teatro para exhibir el retrato del rey y el pendón real, jurar la población ante ellos y repre- 
de Canarias. Junto con la Invención, estas dos entidades deliberan sobre quién es la persona más indicada para saludarlo, y de la leve confrontación dialógica de los personajes conceptuales, de los actantes, surge la necesidad de que sea el caudillo aborigen Doramas - muerto en combate por el conquistador Pedro de Vera (1440$1500)$ en 1480 - quien se encargue de ese cometido. ${ }^{15}$

Por boca de la Invención se nos da la famosa descripción del bosque de Doramas, inmortalizado no sólo en la Comedia del Recebimiento (Cairasco de Figueroa 104-5), sino en varias partes del Templo militante, en el canto XV de Goffredo famoso (una excelente traducción que hizo Cairasco de la Jerusalén libertada de Torcuato Tasso) y en una epístola al Licenciado Gonzalo Mateo de Berrio. Ubicada en el término municipal de Teror hasta su total destrucción en la primera mitad del siglo XIX, la selva de Doramas, cuya historia textual y discursiva ha sido rastreada con detalle por Andrés Sánchez Robayna ("Cairasco" 67-151; "Más sobre la Selva" 193-201), figura como signo sincrético que funde un tópico de procedencia homérica y virgiliana - el tradicional "lugar agradable, ameno" - con un espacio real y cercano al que aspira a acomodarse. Apropiación de un tema literario absorbido de la cultura clásica pero transformado - por vía simbólica - en uno de los emblemas autorreferenciales de Canarias, y que es, en palabras de Carlos Brito Díaz, "consecuencia de un proceso de 'circunstanciación' insular" (Brito Díaz, "Bartolomé Cairasco" 370), 16 el mito

sentar las comedias; 2 . Casas y calles: recorrido procesional con el pendón real: casa capitular $>$ calles $>$ casa del maestre de campo $>$ calles $>$ puerta de la Iglesia $>$ Iglesia $>$ calles $>$ teatro en la plaza; 3. Iglesia: ceremonia religiosa para el Pendón, con aspersión de agua bendita; 4. Personajes: autoridades civiles y militares, jerarquía religiosa, compañías de milicias y vecinos. 5. Movimiento escénico: desfiles precedidos por las autoridades y milicias; ascensos, descensos y cuadro vivo alrededor del retrato y del Pendón; júbilo y jura de la población coautor y espectador, y repartición a granel de monedas de plata con la efigie real" (Azparren Giménez 35).

15 Doramas fue uno de los guerreros indígenas que mostró mayor resistencia a la dominación extranjera en la isla de Gran Canaria. Puede encontrarse un buen acopio de datos históricos sobre este personaje en el artículo de Álvarez Delgado (395-413).

16 Rafael Fernández Hernández se expresa en términos semejantes: “La recepción del exterior (representada por los honores ofrecidos al nuevo prela- 
de la Selva de Doramas evidencia que entre lo extraño y lo propio, entre lo antiguo y lo contemporáneo, entre lo literario y lo real fluyen secretos vasos comunicantes.

Desde el punto de vista de la semiología teatral, observamos que ninguna indicación escénica acompaña a estos pasajes descriptivos, lo que prueba que se trata de signos exclusivamente verbales sin apoyo visual palpable o, a lo sumo, con muy reducido número de elementos decorativos relevantes. Y es que la idealización de la formación boscosa isleña en labios de los personajes de la obra - un "espacio diegético" en su más amplio sentido-, 17 de tan acentuada que es, sólo puede soportarse a través de la palabra como vehículo de comunicación y de la imaginación del espectador como respuesta al estímulo verbal, estilizado al extremo. La imposibilidad de indicar mediante signos escénicos realidades como la selva de Doramas, que en la época de Cairasco todavía conservaba todo su esplendor, obliga a utilizar signos del texto de la obra: un personaje describe a su interlocutor, y, de paso, a los receptores, lo que éstos no ven pero pueden imaginar sin mayores esfuerzos, ya que formaba parte del mundo de su experiencia cotidiana. ${ }^{18}$

Como en toda obra con personajes simbólicos, se distinguen en la comedia dos planos de significación, percibidos por Rafael Fernández en su comentario de la pieza: uno alegórico, simbólico y genérico, encarnado en los personajes de Sabiduría, Curiosidad e Invención, así como en Gáldar y Guía, municipios limítrofes enemistados, pero que se reconcilian para recibir y rendir honores al obispo Rueda; y otro plano bajo y humano - parte de la escena I y sobre todo la III-, que se refiere a los hechos y cosas del común de los mor-

do) se sustantiva en aportación propia a través de esa mirada insular que funde las nuevas ideas con las heredadas en un afán de recreación" (Fernández Hernández, “La percepción” 448).

17 José Luis García Barrientos define el espacio diegético o argumental como "el componente espacial de contenido, un conjunto de los lugares ficticios que intervienen o aparecen, de la forma que sea, en la fábula o argumento; el espacio significado en su integridad, o si se quiere, representado mediante cualquier procedimiento representativo (espacial o verbal, dramático o narrativo, etc.) y no sólo por los específicamente teatrales" (García Barrientos 127-128).

18 Acerca de los procedimientos que indican verbalmente significados que deberían aparecer en escena mediante signos visuales, véase el trabajo de Díez Borque (“Una aproximación” 86-92). 
tales, aunque revestido, en última instancia, de caracteres míticos. Doramas, metáforicamente, se impregna de una significación dual, no fija, "representa en sí la isla, su espíritu de lucha, su natural condición precivilizada y precristiana, que, en virtud de un mágico elixir dado por la Invención, se transmutará en adalid de los valores cristianos y castellanos" (Fernández Hernández, "Introducción" 20). ${ }^{19}$

Siendo un personaje de otra época y alegoría de la valerosidad del pueblo guanche y de fe religiosa, resulta novedosa la aparición del héroe aborigen, no sólo porque éste surge descontextualizado, fuera de su tiempo, aislado en los modos ancestrales de su cultura, sino porque paradójicamente, en la primera intervención de éste, previa a su ulterior metamorfosis, lo vemos conversar con la Sabiduría en su lengua nativa: 20

\section{Sabiduría}

Aguay marene, Aguay marane ayermaraha

\section{Doramas}

Aguay marana en maraguas ay ha acha

Aytimadas ayta ast Autindana ast

Chanbeneguer ast Bentagayre

(Cairasco de Figueroa 107).

19 De la misma manera que se empieza a sacar provecho en el teatro insular escrito en castellano de este tipo de personaje "primitivo", por las mismas fechas el mundo indígena de América gana igualmente en popularidad internacional, y no sólo entra en el teatro compuesto en Hispanoamérica, sino que también en Europa el indio será incorporado a las coreografías de los ballets cortesanos y a la ópera de la restauración inglesa.

20 Estos pasajes en lengua prehispánica son de vital importancia lingüístico-histórica por cuanto han quedado como uno de los escasos vestigios escritos del supuesto habla de los guanches (nombre con que se conoce genéricamente a los indígenas de Canarias). En contraste con lo que sucedió en América Latina, la población aborigen del Archipiélago, muy diezmada tras la conquista e impotente ante la progresiva colonización, acabó integrándose en su totalidad en la nueva sociedad, con el consiguiente abandono de sus señas lingüísticas, de las diferentes lenguas que se hablaban en cada una de las islas, de las que sólo se han conservado algunas palabras referentes a la onomástica y muchos 
Palabras ante las que otro personaje comenta jocosamente: “No lo entendiera la madre que le parió" (Cairasco de Figueroa 108).

La extrañeza de los actantes dialogantes ante una lengua ajena que no comprenden ${ }^{21}$ no excluye la admiración del dramaturgo hacia la raza vencida. Todo lo contrario. Una vez ingerido el bebedizo que le confiere la "ciencia infusa" al bárbaro y rústico Doramas, éste adquiere excelente dominio de la lengua de los conquistadores, en la que refiere elocuentemente la historia de su persona y los dones de su pueblo. Doramas se transforma así en un ser de ademanes civilizados. Todo, menos el ropaje que viste - que, como ha observado Eugenio Padorno, sigue siendo el de los primitivos habitantes de Canarias (Padorno, "Fragmento" 45-48) - ${ }^{22}$ desvela una gama de señales exteriores que repercute en la ambigüedad de su ostensible pero incompleto cambio. Por su forzada naturaleza híbrida, por la ausencia de correlación entre los signos referentes a la vestimenta y los signos lingüísticos supratextuales en la caracterización

términos toponímicos. Seguramente ello explica que en Canarias no se registre la existencia de un teatro vinculado al mundo indígena (misionero y educativo) con elementos tomados de la propia cultura de los nativos, como ocurrió en Hispanoamérica. Las pocas muestras de teatro que han llegado hasta nosotros estaban enfocadas hacia el espectador español o al criollo, como ejemplifica la obra de Cairasco de Figueroa. No obstante, se ha barajado la posibilidad de que el escritor canario hubiera conocido durante su niñez o juventud a viejos isleños nacidos antes de la conquista, suponiendo - cosa bastante improbable - que los aborígenes de la primera generación siguiente a la culminación de la gesta castellana hubieran perdido completamente su propio idioma.

21 Doramas reconoce en la escena III que “Aquel que desató mi lengua muda / y me sacó de la profunda cueva, / me dió poder de mejorar lenguaje, / aunque me lo quitó de mudar traje" (Cairasco de Figueroa 120).

22 No podemos evitar nuevas referencias a Hispanoamérica, donde proliferan las ocasiones en que se representaban comedias para festejar el nacimiento de un príncipe, celebrar el día de un santo patrono, recibir a un nuevo gobernador, con motivo de la jura y aclamación de un rey o con el objetivo de agasajar a un recién llegado virrey o a un obispo: “Conforme al modelo retórico que circulaba en América, tenía el carácter de una cantata circunstancial en encomio de un personaje o para la celebración de algún suceso. Se planeaba el asunto con personajes simbólicos, repartiéndose la trama entre solos y coros. Toda la fuerza de la obra estaba en el lirismo que en toda ella se expresaba y tanto los solos como los coros debían tener aquella entonación propia de un homenaje artístico de alabanza" (Pereira Salas 38). A este linaje de textos pertenecen la Loa en obsequio y celebración del obispo de Santiago de Chile, Dr. Juan 
del personaje, la figura metamórfica del caudillo aborigen isleño sirve de puente entre lo foráneo y lo autóctono, entre el presente y el pasado, entre un ayer heroico, aunque clausurado por los avatares de la Historia, y la actuación de un estado contemporáneo henchido de vigente gloria divina.

La bienvenida que se le hace a Fernando de Rueda en nombre de las siete islas, cuyas virtudes se describen en nueve octavas reales, sale caudalosamente de los labios de este individuo. En realidad, toda la obra preanuncia la llegada del momento cumbre en que se homenajea al recién llegado con una versificación teatralizada en la que el brote de apoteosis emblemática que ve la luz en la última escena campea sobre los restantes elementos constructi$\operatorname{vos}^{23}$ No hay en la composición una acción física jalonada de múltiples incidentes, ni el esquema actancial de oposiciones de la Tragedia y martirio de Santa Caterina de Alejandría, de la Tragedia de Santa Susana y de la Comedia del Alma (personajes "nobles"/personajes "vulgares") opera de la misma manera en esta obra conmemorativa. La ilación lógico-temporal de las diferentes situaciones escenificadas converge en el largo monólogo de Doramas, que ocupa la primera mitad de la tercera escena y que se produce, como ha examinado Fernández Hernández ("Introducción" 20), en tres tiempos: 1) presentación del héroe y del mundo en que vive, con una introducción explicativa dirigida al auditorio y a Rueda, al que llama "pastor

González Melgarejo (1746), Comedia del recibimiento que hizo la Nueva México a la Iglesia, compuesta por el capitán Farfán y representada en 1598, o Desposorio espiritual entre el pastor Pedro y la Iglesia Mexicana, de Juan Pérez Ramírez, escrita con ocasión de la llegada a México del arzobispo Pedro Moya de Contreras (1574), entre otros muchos ejemplos. La representación de Los empeños de una casa, de Sor Juana Inés de la Cruz (1649 o 1651-1695), el 4 de octubre de 1683 en homenaje a los marqueses de la Laguna coincidió asimismo con la entrada en México del nuevo arzobispo Francisco de Aguiar. Amor es más laberinto (1689), de la misma autora, que celebraba el cumpleaños del virrey, se inscribe igualmente en esta línea.

23 También en otro lugar el profesor Padorno insiste en la prolongación, tras la implantación de la lengua castellana en las islas después de la conquista en la última década del siglo XV, de unos esquemas espirituales determinantes que se adecuan al nuevo y extraño vehículo de comunicación (Padorno, “Un “Canario Cántico'” 27).

24 Téngase en cuenta que después de la edición de 1957 no ha visto la luz 
clarísimo" o "sacro pastor", que justifica la manera en que surge en él infusamente el arte de la oratoria (Cairasco de Figueroa 119-122); 2) méritos del obispo en relación con el caudillo aborigen en sus respectivos papeles de jefe de la comunidad indígena y de director de almas (Cairasco de Figueroa 122-126), y 3) elogio de cada una de las islas metamorfoseadas en ninfas (Cairasco de Figueroa 126128).

Al igual que en las demás piezas teatrales de Cairasco, nuevos guiños al espectador a través de la mención de circunstancias verídicas, en este caso la rivalidad entre Guía y Gáldar, topónimos personificados en las escenas II y III, salpican de notas "realistas" el texto dramatúrgico; por ejemplo, al comienzo del diálogo entre Guía y Gáldar el primer municipio le propone al segundo olvidar antiguas rencillas - basadas, al parecer, en la mayor honra de uno y en la mayor riqueza del otro- para acudir juntos a ver al nuevo obispo:

\section{Guía}

Dejando puntos de honor

y competencias pasadas,

Gáldar, vamos con amor

a ver el nuevo pastor

de las islas Fortunadas

(Cairasco de Figueroa 112).

De este modo, a pesar de que hasta el presente las Islas Canarias, por sus reducidas dimensiones geográficas y por su relativa proximidad de la Península, no ha podido - ni siquiera lo ha intentado-librarse del yugo del colonialismo, una temprana muestra de teatro gestado en suelo canario como la Comedia del Recebimiento conforma ya un producto estético peculiar en el que el reiterado apego a la inmediatez isleña por medio de la introducción de personajes históricos como Doramas, la humanización de topónimos como Guía y Gáldar o los comentarios sarcásticos sobre la situación social del Archipiélago sobresalen por encima del efímero evento que le sirve de marco paratextual. Mezcla de abstracción, pasatismo, informaciones emanadas de la realidad inmediata contemporánea, voluntad mitificadora, universalismo y autoctonía, la Comedia del Recebimiento es tal vez la obra teatral de Cairasco que más signos de canariedad exhibe, ya que el dramaturgo, al tiempo que se adueña de la retórica de la época, impuesta en las islas por 
la cultura colonizadora peninsular, inserta la acción homenájica en un espacio reconocible, próximo, que no es otro que el suyo propio. La comedia surge así del cruce entre la cultura del conquistador y el espíritu de los vencidos, asumido como algo que le pertenece. Y es que la adopción del nuevo código lingüístico tras la conquista no supuso, según ha expresado Eugenio Padorno, una erradicación absoluta de los viejos contenidos psicológicos del aborigen ni de su cosmovisión peculiar, que lograron sobrevivir solapadamente y canalizarse a través de la nueva lengua adquirida, de modo que "donde creímos ver un hiato insalvable - entre dos lenguas, entre dos civilizaciones, entre dos eras históricas - hay una ilación que posibilita que un presente subvertido siga encontrando su referencialidad en un pasado sepulto" (Padorno, "Fragmento" 47). ${ }^{24}$ Así pues, el de Cairasco es un teatro mestizo, situado en la encrucijada de una progresiva dinámica aculturadora que todavía conserva rasgos de una etapa inicial de desigual transculturación, no sólo por el deslizamiento en un texto esculpido en lengua española de un supuesto sustrato autóctono en forma de discurso en idioma indígena, tal como debió sonar al oído castellano del autor, sino por la búsqueda identitaria (llamativa al tratarse de la óptica de los vencedores) de un concierto entre la exaltación del heroísmo del pueblo guanche y el feliz advenimiento de un nuevo orden político, social y, sobre todo, religioso al que debe rendirse pleitesía.

En el abordaje crítico de cualquier obra literaria adquiere significativa relevancia tanto su modo de producción como las condiciones de lectura y su proceso interpretativo. Por ello no resulta ocioso hacer hincapié de nuevo en la ocasión de la pieza, que no es otra, como hemos anotado al principio, que una fiesta de recepción, a partir de la cual se estructura la materia dramática. No es éste, pues, un teatro que surja a espaldas de la realidad o aparte de ella, sino, precisamente, a causa de ella; por otro lado, más que para ser leído, es un teatro para ser visto y oído en un momento histórico determinado y en una zona geográfica específica. Y ya estas circunstancias, que deberían llamar la atención de cualquiera que se

ninguna otra. Sí hemos tenido la oportunidad de disfrutar el 28 de mayo de 2002 de una representación de la Comedia, llevada a cabo por la compañía Teatro Universitario Alejandro Cioranescu en el Paraninfo de la Universidad de Las Palmas de Gran Canaria.

25 Se da la coincidencia de que estas manifestaciones se asemejan, salvan- 
acerque a una obra tan inaccesible hoy para el lector corriente como la Comedia del Recebimiento, 25 nos están indicando que la dramatización de la realidad vivida y convivida por el dramaturgo y su público, en la que se conjuga realidad y ficción, supone en su base una interpretación de esa realidad. Al fin y al cabo, más allá de la anécdota y de la escenografía tomada en sus formas más inmediatamente figurativas, el teatro sigue siendo el escaparate del hombre, de sus problemas y de la sociedad en la que se integran, y en él, como espectáculo audiovisual que es, igual de importantes que las palabras comunicadas por los personajes a través de los actores son otras formas complementarias de teatralidad. Dado que el teatro aurisecular se fragua en la intersección entre literatura dramática y espectacularización, conviene resaltar que texto y espectáculo, fusionados en la práctica escénica, comparten un mismo destino. ${ }^{26}$ Se ha dicho que el clasicismo parte del texto, adapta y retrabaja los materiales textuales, sin preocuparse por su presentación visual, que el esquematismo del decorado - a partir de un número muy reducido de elementos pertinentes frente al detallista y acumulativo decorado realista-burgués - denota una escasez de signos que localicen las escenas espacio-temporalmente; sin embargo, en el caso de la Comedia del Recebimiento, lo cierto es que "a la representación de la pieza dramática del día 8 de mayo se suma el espectáculo en la calle, tan del gusto epocal, con las arquitecturas efímeras construidas al efecto para teatralizar el rito de la incorporación del prelado [...] en cuyos arcos figuran letras para cantar, emblemas y epigramas, encargados a Cairasco, si bien el

do las diferencias de cultura y la distancia geográfica, con ciertas costumbres arraigadas en los pueblos indígenas prehispánicos del Nuevo Mundo. Dentro de la cultura precolombina, el teatro era parte de ceremonias religiosas e incluía danzas y cantos. Los participantes recitaban versos acerca de hechos históricos o leyendas (grandes batallas, aventuras de sus héroes y dioses). En las plazas se erigían escenarios o plataformas. Debido a ello, los indios de América estaban preparados para comprender y aceptar las formas hispánicas del teatro. La tradición indígena influyó en el desarrollo posterior de los géneros populares hispanoamericanos; por el contrario, en la práctica teatral canaria del siglo XVI no ha quedado sustrato alguno de una mínima forma de teatralidad atribuible a los guanches.

26 La estampa que nos brinda Brito Díaz sigue de cerca en lo esencial la escueta información recogida por Cioranescu en su artículo de 1957.

27 A falta de una "Relación" que ahonde en los pormenores de esta fiesta 
peso del aparato recayó en otro canónigo", según ha precisado Carlos Brito Díaz ("Bartolomé Cairasco" 357-358). ${ }^{27}$ La teatralidad, entonces, al rebasar los límites de la mera acción encarnada por los personajes diseminados sobre el eventual tablado escénico levantado en la fachada del templo o en su interior, se expande hacia zonas extramuros.

La ausencia casi absoluta de documentación acerca de la realidad escénica del momento en el archipiélago canario y de las condiciones materiales del teatro en todos los elementos que lo integran impide acometer con rigor un estudio profundo de la actividad espectacular que la obra origina, pero es de presumir que la realización del acto se cubriese de la vistosidad requerida para la ocasión, aunque de ello apenas dé cuenta el texto escrito, lo que sumado al parlamento de los actores sobre el escenario aderezado para tal efecto, a su capacidad histriónica, a la expresividad de sus gestos, al colorido de las vestimentas que lucían, a los cantos entonados con acompañamiento instrumental o a los decorados, potencia la concepción de un espectáculo integrador, ante el cual, imaginamos, debieron quedar impresionados los asistentes a la representación. Todos menos, según parece, el propio homenajeado, pues si hacemos caso a lo que Luis de Morales, el canónigo encargado de la parte decorativa, le escribiría a un amigo de la Península, Rueda "fué un obispo tan ingrato, que ni un Dios os dé salud o bueno estava no me dijo" (cit. por Cioranescu, "Cairasco..." 332). ¿No agradó acaso al Reverendísimo el boato desplegado en su honor o quizás se sintió molesto, en particular, por el juego conceptista que los personajes de la comedia "improvisaron" inocentemente a partir del apellido de esa autoridad eclesiástica? Recordemos que al final de la obra, aunque con intención laudatoria, Doramas, Gáldar, Guía, Curiosidad, Invención y Sabiduría recitan cada uno una octava real al estilo de la siguiente:

de recepción, no nos queda otra alternativa que movernos en el terreno resbaladizo de las conjeturas. A la explicación arriba apuntada, cabe agregar el mencionado contenido "criollista" de la obra o el que haya sido Doramas el encargado de representar el sentir unánime del pueblo allí reunido; pero opino que el supuesto desagrado del prelado burgalés habría que atribuirlo más bien a la desconfianza con que la Iglesia contrarreformista miraba desde mediados del siglo XVI determinados elementos "ilícitos" presentes en farsas y comedias.

28 El mandato, que reproducimos a continuación, lo cita Sebastián Padrón 


\section{Curiosidad}

El gobierno del orbe en Rueda estriba, que de Oriente a Poniente es su derrota; y con Rueda la Iglesia se cultiva; y Roma se gobierna por la Rota; Ezequiel es su visión altiva grandes misterios de la Rueda nota: por eso está, señor, Canaria leda, pues la gobierna Dios con vuestra Rueda

(Cairasco de Figueroa 131). ${ }^{28}$

Sin duda, no debió sentir el recién llegado mucha debilidad por los espectáculos teatrales, si nos atenemos al dato de que, tres años después, durante una visita pastoral a Santa Cruz de Tenerife, este mismo dirigente de almas ordenó que las obras representadas en las iglesias los días de Corpus, Navidad, Sábado de Resurrección y otras festividades fuesen evaluadas por un vicario y un teólogo $\mathrm{y}$, si fuese necesario, el texto expurgado antes de autorizarse su representación, habida cuenta de las "cosas indecentes" que solían aparecer en ellas. ${ }^{28}$

En cuanto manifestación festiva, celebración cívico-religiosa, ceremonia o rito, late, pues, en la actividad que rodea a la puesta en escena de la Comedia una voluntad extrateatral que supera el fragmentarismo y limitación del decorado escénico, de tal suerte que a la acción puramente dramática se agregan manifestaciones parateatrales que, lejos de tener exclusiva apoyatura en la escritura o en las acotaciones (de por sí escasas), residen por igual en el vestido, en el gesto y en el deseo de trascender lo cotidiano. Como par-

Acosta: "Item porque las representaciones que se acostumbran hacer en las iglesias el día de Corpus Christi y de Navidad y Sábado de Resurrección y otras festividades suelen hacerse cosas indecentes y tales que no se sufren en santo lugar, el dicho mandaba e mandó de que aquí adelante el Vicario no dé lugar ni consienta que hagan tales representaciones, sin que primero se traiga ante él assí las obras principales como los entremeses, y vistas por él con un teólogo, e si hubiere quitar se quite y enmiende" (cit. por Padrón Acosta 26-27).

29 Esta idea la plasma tal cual Orozco Díaz (109). Véase también Serralta (683-687). 
ticipantes de tal evento, tanto el actor como el público se vuelven conjuntamente parte de un decorado que contornea sus perímetros más allá del claustro y del pórtico de la iglesia, en los que debieron lucir arcos florales, estandartes, emblemas, escudos de armas, luminarias y demás artilugios. Con ese deslizamiento del artificio, de lo fingido en el ámbito natural del hombre, no sólo se está aproximando el teatro a la vida, sino que, en la medida en que el simbolismo ornamental invade el espacio cotidiano, se aprecia un intento de hacer de la vida puro teatro, de sugerir - por medio de la fastuosa puesta en escena - una teatralización de la realidad, fenómeno éste que durante el siglo siguiente alcanzará no solamente a los modos más solemnes y públicos de la corte y la Iglesia, sino a la forma corriente del individual vivir cotidiano, al ser y comportarse del hombre.

Es, indudablemente, el propio texto el que confirma y construye un clima de expectación receptora. Al principio de la obra Sabiduría le informa a Curiosidad de la inminente llegada del obispo Rueda, "persona de tan alto punto y nombre, / que con gran majestad retumba y suena / el eco de su fama en toda parte" (99). Ése es "nuestro gran deseo" (99), según palabras que dice Curiosidad, referidas no sólo a la voluntad de ellas dos como actantes de la ficción teatral, sino a la totalidad de los presentes, espectadores y a la vez partícipes de acontecimiento tan sonado. Guía y Gáldar aparecen por vez primera en la escena II, simbolizando al público congregado para festejar la venida de don Fernando y, por extensión, representando a la isla entera. Y en la última parte, Doramas, que asume el papel de portavoz del público feligrés y de las siete Islas Canarias, se destaca solo en el encuadre escénico de la tarima, cuando la atención se fija en las palabras que le dirige al Sumo Pontífice adoptando un talante servilista que será imitado también después, aunque más brevemente, por el resto de los personajes de la obra, en cuyos discursos la realidad empírica, el espacio objetivo, la dinámica del protocolo, se transfiguran literariamente, al tiempo que, mediante encomiásticas alusiones al motivo concreto de la convocatoria, la ficción, elevada sobre una onda expansiva, se desborda. Tal tentativa de convertir en espacio escénico significativo determinados fragmentos del entorno real y de tornar en representación acciones reales de ese mismo entorno hace de la Comedia del Recebimiento, tanto como de otras piezas conmemorativas de bien entrado el siglo XVI una prefiguración de la idea barroca del mundo como teatro. 


\section{Bibliografía}

Alemany, Luis. El teatro en Canarias. Notas para una historia. Santa Cruz de Tenerife: Ayuntamiento de Santa Cruz de Tenerife, 1996.

Álvarez Delgado, Juan. "Doramas: su verdadera historia." Anales de Estudios Atlánticos 16 (1970): 395-413.

Azparren Giménez, Leonardo. El teatro en Venezuela. Ensayos históricos. Caracas: Alfadil Ediciones, 1997.

Bobes Naves, María del Carmen. Semiótica de la escena. Análisis comparativo de los espacios dramáticos en el teatro europeo. Madrid: Arco/Libros, 2001.

Brito Díaz, Carlos. "El teatro de Canarias: José de Anchieta (15341597) y Cairasco de Figueroa (1538-1510)." El teatro en tiempos de Felipe II Actas de las XXI Jornadas de teatro clásico de Almagro, julio de 1998. Eds. Felipe B. Pedraza Jiménez y Rafael González Cañal. Almagro: Ediciones de la Universidad de Castilla La Mancha / Festival de Almagro, 1999. 99-116.

. "Bartolomé Cairasco de Figueroa." A. A. v. V.. Historia crítica Literatura Canaria. vol I. De los orígenes al siglo XVII. Coordinado por Yolanda Arencibia y Rafael Fernández Hernández. Las Palmas de Gran Canaria: Ediciones del Cabildo de Gran Canaria, 2000. 355-373.

Cazorla León, Santiago y Julio Sánchez Rodríguez. Obispos de Canarias y Rubicón. Madrid: EYPASA, 1997.

Cairasco de Figueroa, Bartolomé. Obras inéditas. I. Teatro. Introducción y notas por Alejandro Cioranescu. Santa Cruz de Tenerife: Goya Ediciones, 1957.

Cioranescu, Alejandro. "El teatro de Cairasco." Estudios de literatura española y comparada. La Laguna: Universidad de La Laguna, 1954. 67-90. 
"Cairasco de Figueroa. Su vida. Su familia. Sus amigos." Anales de Estudios Atlánticos 3 (1957): 275-386.

Díez Borque, José María. “Una aproximación semiológica a la 'escena' del teatro del Siglo de Oro español." Semiología del teatro. Comps. José María Díez Borque y Luciano García Lorenzo. Barcelona: Editorial Planeta, 1975. 49-92.

Los géneros dramáticos en el siglo XVI (El teatro hasta Lope de Vega). Madrid: Taurus Ediciones, 1987.

Fernández Hernández, Rafael. "Introducción." Teatro canario, I (Siglo XVI al XX. Antología. Las Palmas de Gran Canaria: Edirca, 1991. 15-76.

. "La percepción insular del mundo exterior en el teatro canario de los siglos XXVI, XVII y XVIII". Homenaje a José Pérez Vidal. Ed. Carmen Díaz Alayón. La Laguna: Excmo. Cabildo Insular de La Palma/Viceconsejería de Cultura y Deportes del Gobierno de Canarias/Excmo. Cabildo Insular de Gran Canaria/Excmo. Cabildo Insular de Tenerife/Universidad de La Laguna/Excmo. Ayuntamiento de Santa Cruz de La Palma/Sociedad Científica "La Cosmológica", 1993. 443-457.

Galván González, Victoria. “Dramaturgia hagiográfica de Cairasco de Figueroa en el contexto quinientista." La comedia de magia y de santos. Eds. F. J. Blasco, E. Caldera, J. Álvarez Barrientos y R. de la Fuente. Madrid: Júcar, 1992. 25-32.

García Barrientos, José Luis. Cómo se comenta una obra de teatro. Madrid: Editorial Síntesis, 2001.

Martín Montenegro, Salvador F. "Teatro en Canarias, siglos XVI y XVII." De los inicios al siglo XVII. Coord. Yolanda Arencibia y Rafael Fernández Hernández. Las Palmas de Gran Canaria: Ediciones del Cabildo de Gran Canaria, 2000. 477-495. Vol. 1 de Historia Crítica Literatura Canaria.

Millares Carlo, Agustín y Manuel Hernández Suárez. Biobibliografía de escritores canarios (siglos XVI, XVII y XVIII). Vol. II. Valencia/Las Palmas: El Museo Canario/ Plan Cultural, 1977. 
Orozco Díaz, Emilio. El teatro y la teatralidad del Barroco. (Ensayo de introducción al tema). Barcelona: Editorial Planeta, 1969.

Padorno, Eugenio. “Un 'Canario cántico'. La forja de la tradición interna de una literatura hispánica ultraperiférica." Algunos materiales para la definición de la poesía canaria. Las Palmas de Gran Canaria: Ediciones del Cabildo de Gran Canaria, 2000. 19-71.

__ . "Fragmento de un parlamento de Doramas." La parte por el todo. Proposiciones y ensayos sobre poesía canaria. Las Palmas de Gran Canaria: Boca de riego, 2001. 45-48.

— . "Unas notas sobre insularidad." Quimera 205 (julio-agosto 2001): 42-45.

Padrón Acosta, Sebastián. El teatro en Canarias. La fiesta del Corpus. La Laguna: Instituto de Estudios Canarios, 1954.

Pereira Salas, Eugenio. Historia del teatro en Chile desde sus orígenes a la muerte de Juan Casacuberta. Santiago de Chile: Universidad de Chile, 1974.

Sánchez Robayna, Andrés. "Cairasco de Figueroa y el mito de la Selva de Doramas." Estudios sobre Cairasco de Figueroa. La Laguna: Real Sociedad Económica de Amigos del País de Tenerife, 1992. $67-151$

_ . "Más sobre la Selva de Doramas (Notas bibliográficas)." Estudios canarios. Anuario del Instituto de Estudios Canarios 39 (1994) (1995): 193-201.

Serralta, Frédéric. "Teatro y parateatro," Historia del teatro en España. Dirigida por José Ma. Díez Borque. Madrid: Taurus Ediciones, 1983. 683-687. 